\title{
PENGARUH PENGARUH BANTUAN PEMERINTAH, PENGALAMAN DAN LINGKUNGAN USAHA TERHADAP PRODUKTIVITAS KERJA NELAYAN KOPERASI PERIKANAN SINAR MUTIARA SAMUDRA DI DESA SWARANGAN KECAMATAN JORONG KABUPATEN TANAH LAUT
}

\author{
Yuliandi Surya \\ Sekolah Tinggi Ilmu Ekonomi Pancasetia Banjarmasin \\ Jl. Ahmad Yani Km. 5.5 Banjarmasin \\ suryayuliandi@gmail.com
}

\begin{abstract}
Abstrak: Penelitian ini bertujuan untuk mengetahui baik secara parsial dan simultan seberapa besar Pengaruh Bantuan Pemerintah, Pengalaman Dan Lingkungan Usaha Terhadap Produktivitas Kerja Nelayan Koperasi Perikanan Sinar Mutiara Samudra Di Desa Swarangan Kecamatan Jorong Kabupaten Tanah Laut serta variabel yang berpengaruh dominan terhadap Produktivitas Kerja Nelayan Koperasi Perikanan Sinar Mutiara Samudra Di Desa Swarangan Kecamatan Jorong.

Metode yang digunakan dalam penelitian ini adalah metode kuantitatif dan dengan populasi sebanyak 51 (lima puluh satu), diambil sampel dengan teknik sampling sensus sebanyak 51 (lima puluh satu) orang, instrument penelitian uji validitas dan uji reliabilitas, data - data diuji dengan menggunakan regresi linear berganda.

Hasil penelitian ini menunjukkan bahwa (1) Secara simultan Bantuan Pemerintah, Pengalaman dan Lingkungan Usaha berpengaruh signifikan terhadap Produktivitas Kerja Nelayan Koperasi Perikanan Sinar Mutiara Samudra Di Desa Swarangan Kecamatan Jorong Kabupaten Tanah Laut (2) Secara parsial Bantuan Pemerintah, Pengalaman dan Lingkungan Usaha berpengaruh signifikan terhadap Produktivitas Kerja Nelayan Koperasi Perikanan Sinar Mutiara Samudra Di Desa Swarangan Kecamatan Jorong Kabupaten Tanah Laut dan (3) Hasil penelitian menyatakan bahwa variabel yang berpengaruh dominan terhadap Produktivitas Kerja Nelayan Koperasi Perikanan Sinar Mutiara Samudra Di Desa Swarangan Kecamatan Jorong Kabupaten Tanah Laut adalah Lingkungan Usaha. R Square sebesar 0,630 yang berarti besarnya variasi sumbangan seluruh variabel bebas terhadap variabel terikatnya adalah $63 \%$ sedangkan sisanya $37 \%$ dijelaskan oleh sebab lain diluar dari penelitian ini.
\end{abstract}

Kata kunci : Bantuan Pemerintah, Pengalaman, Lingkungan Usaha dan Kinerja. 


\section{Latar Belakang Masalah}

Bantuan Pemerintah adalah pemberian bantuan dari Pemerintah Daerah kepada individu, keluarga, kelompok dan/atau masyarakat. Sifat bantuan ini, tidak secara terus menerus dan selektif. Bantuan ini berupa uang atau barang yang pemberiannya disesuaikan dengan kemampuan keuangan daerah. Tujuannya untuk menunjang pencapaian sasaran program dan kegiatan pemerintah daerah dengan memperhatikan asas keadilan, kepatutan, rasionalitas dan manfaat untuk masyarakat.

Dalam penelitian ini Bantuan Pemerintah adalah bantuan yang diberikan Dinas Kelautan dan Perikanan Provinsi Kalimantan Selatan sebagai organisasi perangkat daerah yang membidangi perikanan di Provinsi Kalimantan Selatan, dimana nelayan bisa mengajukan proposal bantuan peralatan yang diperlukan nelayan dalam menangkap ikan, hal ini dilakukan agar bisa meringankan beban dan membantu nelayan agar lebih produktif dalam bekerja.

Kalimantan Selatan memiliki potensi perikanan yang sangat baik, baik ikan laut atau ikan air tawar yang harus dikembangkan dan diberikan dukungan berupa bantuan pemerintah, pemerintah Provinsi Kalimantan Selatan juga hendaknya terus menambah anggaran dalam pemberian bantuan kepada nelayanan agar produktivitas nelayanan bisa meningkat, pemberian bantuan dari Pemerintah Provinsi Kalimantan Selatan kepada nelayan di dasarkan pada Peraturan Gubernur Nomor 75 Tahun 2020 Tentang Perubahan kedua Atas Peraturan Gubernur Nomor 0105 Tahun 2018 tentang Tata Cara Penganggaran, Pelaksanaan dan Penatausahaan, Pertanggungjawaban dan Pelaporan serta Monitoring dan Evaluasi Hibah dan Bantuan Sosial Yang Bersumber dari Anggaran Pendapatan dan Belanja Daerah (Berita Daerah Provinsi Kalimantan Selatan Tahun 2020 Nomor 75).

Orang yang berpengalaman dalam bekerja memiliki kemampuan kerja yang lebih baik dari orang yang baru saja memasuki dunia kerja, karena orang tersebut telah belajar dari kegiatankegiatan dan permasalahan yang timbul dalam kerjanya. Dengan adanya pengalaman kerja maka telah terjadi proses penambahan ilmu pengetahuan dan ketrampilan serta sikap pada diri seseorang, sehingga dapat menunjang dalam mengembangkan diri dengan perubahan yang ada.Dengan pengalaman yang didapat seseorang akan lebih cakap dan terampil serta mampu melaksanakan tugas pekerjaannya.

Semua nelayan pada Koperasi Perikanan Sinar Mutiara Samudra Di Desa Swarangan Kecamatan Jorong Kabupaten Tanah Laut harus terus belajar dari pengalaman serta saling berbagi pengalaman dari sesama nelayan, nelayan yang lebih senior atau lebih dahulu bekerja sebagai nelayan bisa membagikan pengalaman kerjanya kepada nelayan yang lebih junior hal ini dilakukan agar semua nelayan dapat bekerja dengan baik dan produkif, semua nelayan harus menunjukan sikap kebersamaan dan menghilangkan ego masing masing untuk kemajuan bersama nelayan Koperasi Perikanan Sinar Mutiara Samudra Di Desa Swarangan Kecamatan Jorong Kabupaten Tanah Laut.

Selain Bantuan Pemerintah dan Pengalaman dari nelayan juga diperlukan lingkungan usaha yang baik dan kondusif agar sesama nelayan dapat bekerja dengan baik, bertukar informasi dan berkomunikasi dengan baik dan nyaman. Lingkungan bisnis saat ini memiliki karakteristik yang dinamis, kompleks, berkaitan dengan perubahan teknologi, keterbatasan sumber daya, ekonomi global serta perubahan politik yang tidak menentu (Eriksson, 2008:6). Hal ini menyebabkan setiap perusahaan harus dapat melakukan efisiensi dan efektivitas dalam segala hal untuk memperebutkan konsumen. Sebagai contoh, penerapan teknologi baru dilakukan agar perusahaan lebih kompetitif dalam hal biaya produksi, memperbaiki kualitas produk, dan memiliki pangsa pasar 
yang baik. Hal ini berarti suatu perusahaan harus memiliki pandangan jauh kedepan untuk mendukung kesuksesan perusahaan (vision).

Berdasarkan uraian diatas lingkungan bisnis adalah lingkungan usaha dimana nelayan saat ini menjadikan mata pencaharian sehari - harinya bekerja sebagai pencari ikan dilaut atau nelayan, untuk itu semakin dinamis dan kompetitifnya lingkungan usaha maka mengharuskan Nelayan Koperasi Perikanan Sinar Mutiara Samudra Di Desa Swarangan Kecamatan Jorong Kabupaten Tanah Laut terus berinovasi dan memperluas pemasarannya agar hasil tangkapan nelayan dapat cepat terjual dengan harga yang diinginkan, selain itu nelayan juga harus mempelajari kapan saja jenis - jenis ikan tertentu melimpah dan sulit ditemui sehingga nelayan bisa mengalihkan tangkapannya ke jenis ikan lain pada musim tertentu.

Produktivitas merupakan salah satu komponen yang harus dimiliki oleh suatu lembaga atau perusahaan apabila ingin mencapai tujuan yang telah ditetapkan. Dalam kegiatannya lembaga atau perusahaan harus mampu meningkatkan produktivitas dari waktu ke waktu, karena ini menyangkut terhadap kinerja lembaga tersebut Aspek sumber daya manusia di dalam perusahaan atau lembaga memegang peranan penting, yaitu sebagai salah satu tolak ukur tingkat produktivitas kerja karyawan, dengan pengertian apabila tingkat kualitas sumber daya manusia di dalam sebuah perusahaan itu tinggi atau baik maka tingkat produktivitas kerja karyawan di lembaga tersebut lebih mudah meningkat, begitu pula sebaliknya apabila tingkat kualitas dari sumber daya manusia itu rendah atau kurang maka tingkat produktivitas kerja karyawan tersebut akan sulit untuk meningkat.

Oleh karena itu bagi setiap lembaga yang ingin sukses dalam usahanya, diharuskan untuk lebih meningkatkan perhatiannya terhadap aspek sumber daya manusia yang dimiliki, dengan tujuan agar harapan serta tujuan dapat tercapai.
Berdasarkan uraian diatas, maka penulis tertarik untuk melakukan penelitian dengan judul "Pengaruh Bantuan Pemerintah, Pengalaman dan Lingkungan Usaha Terhadap Produktivitas Kerja Nelayan Koperasi Perikanan Sinar Mutiara Samudra Di Desa Swarangan Kecamatan Jorong Kabupaten Tanah Laut".

\section{Studi Literatur \\ Bantuan Pemerintah}

Berdasarkan Buletin Teknis Nomor

10 Standar Akuntansi Pemerintahan tentang Akuntansi Belanja Bantuan Sosial, Belanja Bantuan Sosial adalah transfer uang atau barang yang diberikan oleh Pemerintah Pusat/Daerah kepada masyarakat guna melindungi diri dari kemungkinan terjadinya risiko sosial.

Berdasarkan Peraturan Menteri Keuangan Republik Indonesia Nomor 81 Tahun 2012 Tentang Belanja Bantuan Sosial Pada Kementerian Negara/Lembaga, Belanja Bantuan Sosial adalah pengeluaran berupa transfer uang, barang atau jasa yang diberikan oleh Pemerintah Pusat/Daerah kepada masyarakat guna melindungi masyarakat dari kemungkinan terjadinya risiko sosial, meningkatkan kemampuan ekonomi dan/atau kesejahteraan masyarakat.

Berdasarkan Buletin Teknis Nomor 10 Standar Akuntansi Pemerintahan tentang Akuntansi Belanja Bantuan Sosial, Transfer uang/barang/jasa dalam belanja bantuan sosial memiliki ketentuan sebagai berikut:

a. Belanja bantuan sosial dapat langsung diberikan kepada anggota masyarakat dan/atau lembaga kemasyarakatan termasuk di dalamnya bantuan untuk lembaga non pemerintah bidang pendidikan dan keagamaan.

b. Belanja bantuan sosial bersifat sementara atau berkelanjutan.

c. Belanja bantuan sosial ditujukan untuk mendanai kegiatan rehabilitasi sosial, perlindungan sosial, jaminan sosial, pemberdayaan sosial, 
penanggulangan kemiskinan dan penanggulangan bencana.

d. Belanja bantuan sosial bertujuan untuk meningkatkan taraf kesejahteraan, kualitas, kelangsungan hidup, dan memulihkan fungsi sosial dalam rangka mencapai kemandirian sehingga terlepas dari risiko sosial.

Berdasarkan definisi diatas Bantuan Pemerintah dalam penelitian ini adalah merupakan bantuan social berupa barang kepada nelayanan oleh Dinas Kelautan dan Perikanan Provinsi Kalimantan Selatan.

\section{Bantuan Pemerintah Kepada Nelayan}

Dalam UU Nomor 11 tahun 2009 tentang Kesejahteraan Sosial dijelaskan bahwa Pancasila dan Undang-Undang Dasar Negara Republik Indonesia Tahun 1945 mengamanatkan negara mempunyai tanggungjawab untuk melindungi segenap bangsa Indonesia dan memajukan kesejahteraan sosial serta melindungi masyarakat dari risiko-risiko sosial yang mungkin timbul. Maka dengan itu dalam penyelenggaraan guna meningkatkan kesejahteraan masyarakat pesisir atau yang bermata pencaharian sebagai nelayan, perlunya campur tangan pemerintah, perlunya evaluasi dan kebijakan yang mampu meningkatkan kesejahteraan nelayan.

Berdasarkan peraturan Kementrian Kelautan dan Perikanan nomor per.15/men/2010 tentang Organisasi Dan Tata Kerja Kementrian Kelautan Dan Perikanan, Tugas Direktorat Pengembangan Usaha Penangkapan Ikan dalam perumusan dan pelaksanaan kebijakan penyusunan norma, standar, prosedur dan kriteria pemberian bimbingan teknis dan evaluasi di bidang usaha penangkapan ikan.

Dalam melaksanakan tugasnya KKP (kementerian kelautan dan perikanan) membangun pogram pembinaan pemberdayaan masyarakat usaha kecil yaitu salah satunya dengan Pengembangan Usaha Mina Pedesaan Perikanan Tangkap (PUMPT) atau sekarang dikenal dengan
PKN yaitu Peningkatan Kesejahteraan Nelayan. KKP memberikan bantuan langsung disub sektor perikanan tangkap, budidaya ikan dan pengolahan ikan. Untuk mendapatkan bantuan tersebut disalurkan melalui kelompok-kelompok tertentu, dana bantuan yang diberikan digunakan untuk memperbaiki jaring, perawatan mesin, memperbanyak alat tangkap, yang diharapkan akan meningkatkan hasil tangkap ikan nelayan. Sehubungan dengan uraian di atas, hasil penangkapan ikan yang dipengaruhi oleh jumlah tenaga kerja nelayan dan alat tangkap yang digunakan, tidak terlepas dari bantuan pemerintah untuk meningkatkan kesejahteraan masyarakat pesisir, maka bantuan yang diberikan pemerintah akan mempengaruhi pada operasional nelayan dalam melakukan penangkapan. Semakin tinggi bantuan pemerintah yang diberikan kepada nelayan, ada kemungkinan hasil tangkapannya juga akan semakin meningkat.

\section{Dasar Hukum Bantuan Pemerintah Kepada Nelayan}

Adapun dasar hukum pemberian bantuan dari pemerintah kepada nelayan di Provinsi Kalimantan Selatan adalah :

1. Peraturan Menteri Dalam Negeri Republik Indonesia Nomor 123 Tahun 2018 Tentang Perubahan Keempat Atas Peraturan Menteri Dalam Negeri Nomor 32 Tahun 2011 Tentang Pedoman Pemberian Hibah Dan Bantuan Sosial Yang Bersumber Dari Anggaran Pendapatan Dan Belanja Daerah.

2. Peraturan Menteri Kelautan Dan Perikanan Republik Indonesia Nomor 2/Permen-Kp/2015 Tentang Larangan Penggunaan Alat Penangkapan Ikan Pukat Hela (Trawls) Dan Pukat Tarik (Seine Nets) Di Wilayah Pengelolaan Perikanan Negara Republik Indonesia

3. Peraturan Direktorat Jendral Pengelolaan Ruang Laut Nomor 5/PER/DJPRL/2020 Tentang Petunjuk Teknis Penyaluran Bantuan Pemerintah Saran dan Prasarana di 
Wilayah Pesisir dan Pulau Pulau Kecil Tahun 2020.

4. Peraturan Gubernur Kalimantan Selatan Nomor 0105 Tahun 2018 tentang Tata Cara Penganggaran, Pelaksanaan Penatausahaan, Pertanggungjawaban dan Pelaporan serta Monitoring dan Evaluasi Hibah dan Bantuan Sosial Yang Bersumber dari Anggaran Pendapatan dan Belanja Daerah (Berita Daerah Provinsi Kalimantan Selatan Tahun 2018 Nomor 105) sebagaimana telah diubah beberapa kali, terakhir dengan Peraturan Gubernur Kalimantan Selatan Nomor 075 Tahun 2020 tentang Perubahan kedua Atas Peraturan Gubernur Nomor 0105 Tahun 2018 tentang Tata Cara Penganggaran, Pelaksanaan dan Penatausahaan, Pertanggungjawaban dan Pelaporan serta Monitoring dan Evaluasi Hibah dan Bantuan Sosial Yang Bersumber dari Anggaran Pendapatan dan Belanja Daerah (Berita Daerah Provinsi Kalimantan Selatan Tahun 2020 Nomor 75);

\section{Pengalaman}

Pengalaman merupakan suatu proses pembelajaran dan pertambahan perkembangan potensi bertingkah laku baik dari pendidikan formal maupun nonformal atau bisa diartikan sebagai suatu proses yang membawa seseorang kepada suatu pola tingkah laku yang lebih tinggi.

Suatu pembelajaran juga mencakup perubahan yang relatif tepat dari perilaku yang diakibatkan pengalaman, pemahaman dan praktek (Knoers \& Haditono, 2009 dalam Asih, 2012). Purnamasari (2011) dalam Asih (2012:87) memberikan kesimpulan bahwa seorang karyawan yang memiliki pengalaman kerja yang tinggi akan memiliki keunggulan dalam beberapa hal diantaranya: Mendeteksi kesalahan, memahami kesalahan, dan mencari penyebab munculnya kesalalahan.

Pengalaman kerja seseorang menunjukan jenis-jenis pekerjaan yang pernah dilakukan seseorang dan memberikan peluang yang besar bagi seseorang untuk melakukan pekerjaan yang lebih baik. Semakin luas pengalaman kerja seseorang, semakin terampil melakukan pekerjaan dan semangkin sempurna pola berpikir dan sikap dalam bertindak untuk mencapai tujuan yang telah ditetapkan (Puspaningsih, 2004:11). Murphy dan Wrigth (2006) dalam Sularso dan Naim (2009:65) memberikan bukti empiris bahwa seseorang yang berpengalaman dalam suatu bidang subtantif memiliki lebih banyak hal yang tersimpan dalam ingatannya.

\section{Faktor - Faktor Yang Mempengaruhi Pengalaman Kerja}

Ada beberapa faktor yang mempengaruhi pengalaman kerja. Mengingat pentingnya pengalaman kerja dalam suatu perusahaan maka dipikirkan juga tentang faktor-faktor yang mempengaruhi pengalaman kerja.

Menurut Handoko (2009:88) faktor-faktor yang mempengaruhi pengalaman kerja adalah sebagai berikut :

1. Sikap dan kebutuhan (attitudes and needs) untuk meramalkan tanggung jawab dan wewenang seseorang.

2. Kemampuan - kemampuan analitis dan manipulatif untuk mempelajari kemampuan penilaian dan penganalisaan. Keterampilan dan kemapuan tehnik, untuk menilai kemampuan dalam pelaksanaan aspekaspek tehnik pekerjaan

Ada beberapa hal juga untuk menentukan berpengalaman tidaknya seorang karyawan yang sekaligus sebagai indikator pengalaman kerja yaitu:

1. Lama waktu/masa kerja. Ukuran tentang lama waktu atau masa kerja yang telah ditempuh seseorang dapat memahami tugas-tugas suatu pekerjaan dan telah melaksanakan dengan baik.

2. Tingkat pengetahuan dan ketrampilan yang dimiliki. Pengetahuan merujuk pada konsep, prinsip, prosedur, kebijakan atau informasi lain yang dibutuhkan oleh karyawan. 
Pengetahuan juga mencakup kemampuan untuk memahami dan menerapkan informasi pada tanggung jawab pekerjaan. Sedangkan ketrampilan merujuk pada kemampuan fisik yang dibutuhkan untuk mencapai atau menjalankan suatu tugas atau pekerjaan

3. Penguasaan terhadap pekerjaan dan peralatan. Tingkat penguasaan seseorang dalam pelaksanaan aspekaspek tehnik peralatan dan tehnik pekerjaan (Foster, 2001:21).

Dari uraian tersebut dapat diketahui, bahwa seorang yang berpengalaman akan memiliki gerakan yang mantap dan lacar, gerakannya berirama, lebih cepat menanggapi tandatanda, dapat menduga akan timbulnya kesulitan sehingga lebih siap menghadapinya, dan bekerja dengan tenang serta dipengaruhi faktor lain yaitu: lama waktu/masa kerja seseorang, tingkat pengetahuan atau ketrampilan yang telah dimiliki dan tingkat penguasaan terhadap pekerjaan dan peralatan. Oleh karena itu seorang karyawan yang mempunyai pengalaman kerja adalah seseorang yang mempunyai kemampuan jasmani, memiliki pengetahuan dan ketrampilan untuk bekerja serta tidak akan membahayakan bagi dirinya dalam bekerja.

\section{Ukuran Pengalaman Kerja}

Pengukuran pengalaman kerja sebagai sarana untuk menganalisa dan mendorong efisiensi dalam pelaksanaan tugas pekerjaan. Beberapa hal yang digunakan untuk mengukur pengalaman kerja seseorang adalah :

1. Gerakkannya mantap dan lancarsetiap karyawan yang berpengalaman akan melakukan gerakan yang mantap bekerja tanpa disertai keraguan.

2. Gerakannya berirama Artinya terciptanya dari kebiasaan dalam melakukan pekerjaan sehari-hari.

3. Lebih cepat menanggapi tanda-tanda artinya tanda-tanda seperti akan terjadi kecelakaan kerja.
4. Dapat menduga akan timbulnya kesulitan sehinga lebih siap menghadapi, Karena didukung oleh pengalaman kerja dimilikinya maka seorang pegawai yang berpengalaman dapat menduga akan adanya kesulitan dan siap menghadapinya.

5. Bekerja dengan tenang seorang pegawai yang berpengalaman akan memiliki rasa percaya diri yang cukup besar

\section{Pengertian Lingkungan Usaha}

Buchory dan Saladin (2010:46) mengemukakan bahwa: Lingkungan (environment) merupakan salah satu faktor yang sangat diperhitungkan dalam pengelolaan kegiatan bisnis. Lingkungan sangat berpengaruh dalam perencanaan strategi bisnis.

Menurut Glueck and Jauch dalam penelitian Wispandono (2010:154) mengemukakan bahwa: Lingkungan bisnis meliputi faktor-faktor di luar perusahaan yang dapat menimbulkan peluang atau ancaman bagi perusahaan. Analisis diartikan sebagai penelusuran peluang atau ancaman sampai ke pangkalnya. Analisis lingkungan diartikan sebagai proses yang digunakan perencana strategi untuk memantau sektor lingkungan dalam menentukan peluang atau ancaman terhadap perusahaan.

$$
\text { Suryana (2006: }
$$

mengemukakan bahwa: Lingkungan usaha dapat menjadi pendorong maupun penghambat jalannnya perusahaan. Lingkungan yang dapat mempengaruhi jalannya usaha/ perusahaan adalah lingkungan internal dan eksternal.

Buchory dan Saladin (2010:46-47) mengemukakan beberapa alasan pentingnya analisis faktor lingkungan dilakukan, yaitu sebagai berikut:

1. Lingkungan berubah sangat cepat atau dinamis sehingga para pimpinan perusahaan perlu mennganalisis dan mendiagnosis perubahan lingkungan tersebut.

2. Para pimpinan perlu menyelidiki lingkungan, khususnya untuk: 
a. Menentukan apakah faktor-faktor dalam lingkungan saat sekarang mengancam strategi dan pencapaian tujuan perusahaan.

b. Menentukan apakah faktor-faktor dalam lingkungan saat sekarang mengancam strategi dan pencapaian tujuan perusahaan.

3. Perusahaan yang secara sistematis melakukan analisis dan diagnosis lingkungan umumnya lebih efektif dibandingkan dengan yang tidak melakukannya.

Dapat disimpulkan bahwa factor lingkungan sangat berpengaruh dalam menjalankan sebuah perusahaan, dengan lingkungan yang dinamis dan strategi memungkinkan perusahaan akan berkembang sangat cepat.

\section{Dimensi Lingkungan Usaha}

Lingkungan organisasi merupakan variabel yang sangat penting dalam menentukan strategi bisnis perusahaan dan dipandang sebagai trend perubahan yang dapat menciptakan kesempatan dan tantangan bagi organisasi (Swamidass \& Newell, 2007:31). Lingkungan bisnis menjadi elemen kausal dalam hubungan strategi operasi dan kinerja bisnis perusahaan sehingga organisasi perlu melakukan "scanning environment" secara berkesinambungan untuk menjaga kelangsungan hidup organisasi.

$$
\text { Literatur konseptual tentang }
$$

lingkungan bisnis telah dikembangkan dalam literatur manajemen (Dess \& Beard, 1984; Sharfanan \& Dean, 1991 dikutip dalam Badri et al., 2000:11). Dimensi dimensi tersebut meliputi environmental munificence, environmental dynamism, dan environmental complexity. Environmental munificence merupakan tingkat dukungan lingkungan terhadap pertumbuhan organisasi yang ada di dalamnya dan diukur melalui tiga hal yaitu biaya bisnis, ketersediaan tenaga kerja, dan tingkat persaingan. Biaya bisnis mewakili semua biaya produksi yang dibutuhkan perusahaan dalam kegiatan operasional. Ketersediaan tenaga kerja mewakili fokus pada pengurangan teknisi, clerical, dan pekerja produksi. Tingkat persaingan mencakup fokus pada penurunan permintaan baik dalam pasar lokal maupun pasar asing dan fokus pada profit margin yang rendah dan standar kualitas permintaan.

Dinamisme

menunjukkan kondisi perubahan lingkungan yang tidak dapat diprediksi (Dens \& Beard, 1984 dikutip dalam Ward et al, 1995:45). Kondisi ini mengukur tingkat produk dan jasa dalam proses, dan tingkat perubahan selera, serta preferensi konsumen.

Lingkungan yang dinamis mengindikasikan suatu lingkungan yang berubah cepat dan diskontinu dalam hal permintaan, pesaing, teknologi, dan peraturan seperti informasi yang tidak akurat, tidak tersedia, dan ketinggalan jaman. Kompleksitas lingkungan mewakili heterogenitas dalam aktivitas organisasi. Bourgeouis (1980) mengemukakan bahwa kompleksitas lingkungan merupakan fokus yang lebih relevan untuk strategi perusahaan dari pada pada level analisis unit bisnis. Penyebab ketidakpastian dan turbulensi lingkungan bisnis terkait dengan kebutuhan, selera konsumen, peningkatan kompetisi, perubahan teknologi, dan isu sosial ekonomi (Braglia \& Petroni, 2000:22).

\section{Faktor - Faktor Lingkungan Usaha 1. Lingkungan Internal}

Herry Achmad Buchory dan Djaslim Saladin (2010: 49) mengemukakan bahwa Lingkungan internal adalah "para pelaku yang secara langsung berkaitan dengan lingkungan, yang mempengaruhi perusahaan". Wispandono (2010:155) lingkungan internal adalah ,lingkungan organisasi yang ada di dalam suatu organisasi. Analisis ini ditujukan untuk mengetahui kekuatan dan kelemahan organisasi relatif dibanding dengan para pesaingnya ${ }^{e e}$.

Menurut Suci (2008: 337) dalam penelitiannya berpendapat bahwa 
"secara internal, lingkungan perusahaan adalah organisasi perusahaan itu sendiri beserta elemen-elemen di dalamnya". Menurut Saydam dalam penelitian Darya (2011: 66) bahwa, "lingkungan internal mungkin dapat dikendalikan secara organisator oleh pelaku usaha sehingga dapat diarahkan sesuai dengan keinginan perusahaan".

Menurut Buchory dan Saladin (2006:48) Proses analisis lingkungan internal penting dilakukan oleh perencanaan strategi dengan urutan sebagai berikut:

1). Menganalisis hubungan antara strategi perusahaan dan tanggapan terhadap lingkungan, yang dapat dipakai sebagai landasan untuk membandingkan strategi yang sedang berjalan dengan strategi yang potensial yang akan datang.

2). Menganalisis kecenderungan faktor dan masalah utama yang diperkirakan mempunyai dampak penting terhadap perumusan strategi.

3). Mencoba meramalkan kemungkinan yang akan terjadi pada masa yang akan datang terhadap lingkungan.

\section{Lingkungan Eksternal}

Menurut Buchory dan Saladin (2010:51-54) lingkungan eksternal adalah "kekuatan-kekuatan yang timbul dan berada diluar jangkauan serta biasanya terlepas dari situasi operasional perusahaan."

Menurut Pearce and Robinson; Hunger and Whelen dalam penelitian Darya (2011:66) adalah : "menyatakan bahwa Lingkungan eksternal suatu perusahaan memberikan banyak tantangan yang dihadapi oleh sebuah perusahaan dalam upaya untuk menarik atau memperoleh sumber daya yang diperlukan dan untuk memasarkan barang dan jasanya secara menguntungkan".

Menurut Pierce and Robinson dalam penelitian Wispandono (2010:154) adalah : "Lingkungan eksternal adalah lingkungan yang berada diluar organisasi yang dapat menciptakan peluang dan ancaman atas keberadaan suatu organisasi. Dari beberapa pendapat diatas, dapat disimpulkan bahwa yang dimaksud dengan lingkungan Eksternal adalah lingkungan yang berada di luar perusahaan yang secara langsung maupun tidak langsung dapat berdampak pada kegiatan perusahaan/usaha dan dapat menciptakan peluang atau ancaman bagi perusahaan.

\section{Indikator Lingkungan Usaha}

Berdasarkan hasil penelitian dari Wispandono (2010: 154) bahwa, ada 4 indikator Lingkungan Bisnis

1. Biaya Bisnis

a) Peningkatan biaya tenaga kerja

b) Peningkatan biaya material

c) Peningkatan biaya pengangkutan bahan mentah dan barang jadi

d) Peningkatan biaya penyewaan gedung

2. Ketersediaan Tenaga kerja

a) Pengurangan staf manajerial dan administrasi

b) Pengurangan teknisi

c) Pengurangan staf produksi

3. Tingkat Pesaing

a) Tajamnya persaingan dalam pasar lokal

c) Peningkatan permintaan konsumen

c) Produksi untuk memenuhi standar kualitas

4. Dimensi Pasar

a) Tingkat produk dan jasa menjadi ketinggalan dibanding pesaing

b) Tingkat inovasi produk baru

\section{Pengertian Produktivitas Kerja}

Menurut Hasibuan dalam Edyun (2012:65) produktivitas adalah meningkatnya output (hasil) yang sejalan dengan input (masukan). Jika produktivitas naik ini hanya dimungkinkan oleh adanya peningkatan efisiensi (waktu, bahan, tenaga) dan sistem kerja, teknik produksi 
dan adanya peningkatan keterampilan dari tenaga kerjanya.

Produktivitas kerja Siagian dalam Agustin (2014:12) adalah kemampuan menghasilkan barang/jasa dari berbagai sumber daya dan kemampuan yang dimiliki oleh setiap pekerja/karyawan. Secara umum, produktivitas dapat diartikan sebagai kemampuan meningkatkan hasil kerja karyawan yang ditinjau dari sumber daya yang dimiliki oleh setiap masing-masing individu.

Menurut Jackson, dalam Agustin (2014:32) Produktivitas (productivity) diartikan sebagai meningkatnya hasil kerja yang dipengaruhi oleh kemampuan para karyawan (input) dan menghasilkan sebuah barang atau jasa (output).

Wexley dan Yukl dalam Edyun (2012:22) menyatakan produktivitas kerja karyawan dari suatu organisasi memegang peranan yang sangat penting. Karena maju mundurnya organisasi sangatlah tergantung pada naik turunnya produktivitas kerja karyawan. Seorang karyawan yang melakukan sesuatu jenis pekerjaan tertentu dapat dipastikan akan memperoleh hasil. Hasil adalah output akan produksi dari suatu aktivitas kerja.

Produksi atau produktivitas adalah dua hal yang mempunyai hubungan yang erat dan merupakan masalah yang pokok dalam perusahaan. Produksi adalah merupakan suatu usaha untuk menghasilkan barang atau jasa, sedangkan produktivitas berkaitan erat sebagai cara pencapaian tingkat produksi tersebut.

Menurut Maurits (2010:11) produktivitas yaitu mengandung pengertian sebagai sikap mental yang selalu berpandangan bahwa mutu kehidupan hari ini harus lebih baik dari kemarin dan esok harus lebih baik dari hari ini. Filosofi dan spirit tentang produktivitas sudah ada sejak awal peradaban manusia karena makna produktivitas adalah keinginan (the will) dan upaya (effort) manusia untuk selalu meningkatkan kualitaskehidupan dan penghidupan di segala bidang. Produktivitas adalah bagaimana menghasilkan atau meningkatkan hasil barang dan jasa setinggi mungkin dengan memanfaatkan sumber daya secara efisien.

Menurut Internasional Labour Organisation dalam Solihah (2012:32) adalah tingkat efisiensi pemanfaatan setiap elemen yang digunakan untuk produksi pada waktu tertentu. Cascio dalam Almigo (2004:11) performance appraisal atau penilaian kerja yang merupakan suatu penggambaran sistematis tentang individu atau kelompok yang berkaitan dengan kelebihan dan kekurangan dalam suatu pekerjaan sebagai bentuk evaluasi bagi indiviu yang berkaitan dengan pelaksanaan organisasinya

Berdasarkan beberapa refrensi tersebut, dalam penelitian Agustin (2014:23) mengenai produktivitas kerja tersebut dapat disimpulkan bahwa produktivitas adalah meningkatnya hasil kerja yang dipengaruhi oleh kemampuan para karyawan (input) dan menghasilkan sebuah barang atau jasa (output).

\section{Faktor - Faktor Yang Mempengaruhi Produktivitas Kerja}

Menurut Manullang, dalam Edyun (2012:22) memberi penjelasan bahwa faktor-faktor yang dapat mempengaruhi produktivitas kerja adalah:

a. Keahlian, merupakan faktor penting dan harus dimiliki oleh pengawas pelaksana maupun pemimpin.

b. Pengalaman, faktor pengalaman sangat erat hubungannya dengan intelegensi, yaitu kesanggupan karyawan dalam menyelesaikan tugastugas tertentu dengan hasil yang tidak saja ditentukan oleh pengalaman tertentu tapi juga harus didukung oleh intelegensi.

c. Umur, umumnya karyawan yang sudah berumur lanjut mempunyai tenaga fisik relative terbatas daripada karyawan yang masih muda, untuk itu lebih banyak mengenakan karyawan yang lebih muda karena fisiknya lebih kuat.

d. Keadaan fisik, keadaan fisik erat hubungannya dengan tugas yang 
dihadapi. Misalnya pekerjaan yang membutuhkan tenaga fisik

e. Pendidikan, pendidikan sering dihubungkan dengan latihanlatihan yang umunya menunjukan kesanggupan kerja.

f. Bakat dan temperamen, mempunyai peranan penting dalam menunjang kesuksesan kerja. Bakat dan temperamen berhubungan dengan sifat-sifat khusus dari kepribadian seseorang dan dianggap bukan dipengaruhi oleh alam sekitar.

Secara geris besar faktor-faktor yang berpengaruh tergadap produktivitas kerja adalah Maurits (2010:45) :

a. Faktor dari dalam diri pekerja misalnya, keadaan psikis, fisik (kelelahan pekerja) , usia, bakat, karakter, pengalaman, keahlian, pendidikan, kepuasan kerja, motivasi kerja, semangat kerja, dan persepsi pekerja terhadap gaji.

b. Faktor dri luar diri pekerja misalnya penerangan, kebisingan, musik ditempat kerja, waktu istirahat, jam kerja, system penggajian, dan tanggung jawab keluarga.

Pada bagian lain Robbins dalam Maurits (2010:23) membagi faktor-faktor yang mempengaruhi produktivitas kerja dalam tiga bidang pada model prilaku organisasi yaitu secara individual, kelompok dan organisasi. Secara individual produktivitas kerja dipengaruhi oleh ciri biografis, kepribadian, persepsi, dan motivasi. Secara kelompok produktivitas kerja dipengaruhi oleh kepemimpinan, struktur kelompok, kekuatan, politik, komunikasi, konflik. Secara organisasi produktivitas kerja dipengaruhi oleh sumber daya manusia, peraturan-peraturan, stress kerja, kebudayaan, dam struktur kerja.

Menurut Simanjuntak dalam Agustin (2014:13) ada tiga faktorfaktor yang mempengaruhi produktivitas tenaga kerja adalah :

a. Kualitas dan kemampuan fisik karyawan Kualitas dan kemampuan fisik karyawan dipengaruhi juga oleh
Pengalaman, latihan, motivasi kerja, kelelahan fisik dan kemampuan fisik karyawan yang bersangkutan.

b. Sarana pendukung Sarana pendukung untuk meningkatkan produktivitas karyawan digolongkan menjadi 3 (tiga) bagian yaitu:

a) Menyangkut lingkungan kerja termasuk sarana dan peralatan yang digunakan, tehnologi dan cara produksi, tingkat keselamatan dan kesehatan kerja serta suasana lingkungan kerja itu sendiri.

b) Menyangkut kesehatan karyawan yang tercermin dalam sistem pengupahan dan jaminan sosial serta jaminan keselamatan kerja.

c) Sarana, apa yang terjadi didalam perusahaan dipengaruhi juga oleh apa yang terjadi diluarnya, seperti sumber-sumber faktor produksi yang akan digunakan prospek pemasaran, perpajakan, perijinan dll.

\section{Aspek - Aspek Produktivitas Kerja}

Produktivitas kerja menurut Jackson dalam Agustin (2014:11) mengatakan bahwa ada empat aspek yang menentukan besar kecilnya produktivitas kerja seseorang, antara lain :

1. Keterampilan

Dimana setiap pekerja ingin dengan segera menyelesaikan pekerjaannya dan memiliki motivasi untuk berkembang

2. Kemampuan

Berusaha meningkatkan kemampuan dan kualitas kerja

3. Sikap

Memiliki sikap yang siap dan sigap serta loyalitas dalam bekerja

4. Perilaku

Dimana setiap pekerja selalu ingin meningkatkan hasil produksi dan setiap pekerja selelau bekerjasama dalam berbagai hal 


\section{Penelitian Terdahulu}

Adapun perbandingan hasil penelitian terdahulu dengan penelitian saat ini dapat di lihat dibawah ini :

1. Afrillia, Pratiwi .2016. Pengaruh Pengalaman Kerja, Kemampuan Kerja, Fasilitas, Pembagian Kerja Dan Teamwork Terhadap Produktivitas Kerja Nelayan Budidaya Kuda Laut Kampung X. Populasi dalam penelitian ini adalah nelayan yang bergabung dalam membudidayakan kuda laut di kampung melayu senggarang. Teknik pengambilan sampel yang digunakan adalah teknik sampling jenuh. Sampel dalam penelitian ini berjumlah 30 orang. Data yang digunakan dalam penelitian ini adalah data primer yang diperoleh melalui kuesioner. Data yang terkumpul diuji dan dianalisis menggunakan program SPSS 24. Pada kuesioner dilakukan uji validitas dan realibilitas. Berdasarkan hasil penelitian ini diketahui bahwa hasil uji regresi linear berganda yaitu $\mathrm{Y}=-16,356+$ 0,500 Pengalaman Kerja (X1) + 0,305 Kemampuan Kerja (X2) + 0,366 Fasilitas (X3) + 0,437 Pembagian Kerja (X4) + 0,280 Teamwork (X5), uji secara parsial variabel pengalaman kerja, kemampuan kerja, fasilitas, pembagian kerja, dan teamwork berpengaruh signifikan terhadap produktivitas kerja. Hasil pengujian secara simultan memperoleh nilai 51,335 dapat dikatakan bahwa Pengujian secara simultan membuktikan bahwa pengalaman kerja, kemampuan kerja, fasilitas, pembagian kerja dan teamwork berpengaruh signifikan terhadap produktivitas kerja. Kata Kunci : Pengalaman Kerja, Kemampuan Kerja, Fasilitas, Pembagian Kerja, Teamwork dan Produktivitas Kerja.

2. Dea Kamalia Putri. 2018. Pengaruh Bantuan Dana Usaha Produktif
Terhadap Pendapatan Nelayan Di Desa Sungai Limau Kabupaten Mempawah. Metode dalam penelitian ini adalah deskriptif. Ini korelasional penelitian. Jumlah sampel dalam penelitian ini sebanyak 60 orang nelayan. Pengambilan sampel Teknik dalam penelitian ini adalah sampling jenuh. Teknik pengumpulan data dalam hal ini penelitian adalah teknik komunikasi langsung (pedoman wawancara), tidak langsung teknik komunikasi (angket), dan teknik documenter (dokumentasi). Hasil penelitian menunjukkan bahwa (1) persentase Variabel dana usaha produktif di Desa Sungai Limau Kecamatan Sungai Kunyit Of mempawah $71,67 \%$ dalam kategori sedang dengan interval $44,57 \% \leq \mathrm{X}$ $<50,49 \%$, (2) persentase variabel pendapatan nelayan sebesar $66,66 \%$ pada kategori sedang dengan Interval $21,31 \% \leq \mathrm{X}<26,65 \%$, (3) t hitung 4,986> t tabel 2,002 sehingga Ho ditolak dan Ha diterima maka terdapat pengaruh yang signifikan dari dana usaha produktif untuk pendapatan nelayan di Desa Sungai Limau Kecamatan Sungai Kunyit Of mempawah untuk $30 \%$.

3. Nadia June Mawa Dewayanti. 2018. Pengaruh Pengalaman Kerja, Modal, Jam Kerja Dan Jumlah Anggota Keluarga Terhadap Pendapatan Nelayan Di Desa Asemdoyong Kecamatan Taman, Kabupaten Pemalang. Penelitian ini bertujuan untuk menganalisis pengaruh pengalaman kerja, modal, jam kerja dan jumlah anggota keluarga terhadap pendapatan nelayan Desa Asemdoyong, Kabupaten Pemalang. Penelitian ini dilakukan dengan metode wawancara dan survey terhadap nelayan pemilik di Desa Asemdoyong dan dianalisis dengan regresi linier berganda dengan pendekatan OLS (Ordinary Least Square) dengan menggunakan software SPSS Statistic. Variabel 
dependen yang digunakan adalah pendapatan nelayan dengan variabel pengalaman kerja, modal, jam kerja dan jumlah anggota keluarga sebagai variabel independen. Data yang digunakan dalam penelitian ini data primer yang diperoleh melalui wawancara dengan kuesioner dan data sekunder yang diperoleh melalui buku - buku dan literatur - literatur. Penelitian ini menggunakan 79 sampel nelayan Desa Asemdoyong. Hasil penelitian menunjukkan bahwa variabel pengalaman kerja, modal, jam kerja dan jumlah anggota keluarga berpengaruh secara signifikan terhadap pendapatan nelayan Desa Asemdoyong, Kabupaten Pemalang.

\section{Motode Penelitian}

Lokasi Penelitian

Jalan Hangtuah RT.03 Dusun 02

Desa Swarangan, Kecamatan Jorong, Kabupaten Tanah Laut, Kalimantan Selaan Telepon 081348344131 dan Email : koperasi.sinar.mutiara.samudra@gmail.co $\mathrm{m}$.

Jalan Hangtuah RT.03 Dusun 02 Desa Swarangan, Kecamatan Jorong, Kabupaten Tanah Laut, Kalimantan Selaan Telepon 081348344131 dan Email :

koperasi.sinar.mutiara.samudra@gmail.co $\underline{\mathrm{m}}$.

\section{Populasi}

Populasi Sugiyono, (2006:81) adalah wilayah generalisasi yang terdiri atas obyek/subyek yang mempunyai kualitas dan karakteristik tertentu yang ditetapkan untuk dipelajari dan kemudian ditarik kesimpulannya. Populasi pada penelitian ini adalah seluruh Nelayan Koperasi Perikanan Sinar Mutiara Samudra Di Desa Swarangan Kecamatan Jorong Kabupaten Tanah Laut yang berjumlah 51 (lima puluh satu orang) orang.

\section{Sampel}

Pengambilan sampel penelitian harus seksama dan memenuhi aturanaturan dalam pemilihan sampel. Sebagai acuan apabila subyek kurang dari 100 maka lebih baik diambil seluruhnya, sehingga penelitiannya merupakan penelitian populasi Arikunto, (2006:57).

Metode sampling yang digunakan dalam penelitian ini adalah metode sensus. pemilihan metode sensus dalam penelitian ini didasarkan pada pertimbangan bahwa seluruh populasi dijadikan sampel atau seluruh Nelayan Koperasi Perikanan Sinar Mutiara Samudra Di Desa Swarangan Kecamatan Jorong Kabupaten Tanah Laut yang berjumlah 51 (lima puluh satu) orang. oleh karena itu seluruh populasi dijadikan sebagai sampel

\section{Teknik Pengumpulan Data}

Teknik pengumpulan data yang digunakan dalam penelitian adalah:

1. Penelitian Pustaka (Liberary Research)

Data yang diperoleh dengan cara studi kepustakaan (library research) yaitu teknik pengumpulan data-data dengan mengacu pada buku-buku, laporanlaporan penelitian jurnal - jurnal, majalah, koran, pendapat-pendapat para ahli yang dianggap mempunyai hubungan dengan penelitian ini, yang dapat dijadikan sumber data.

2. Penelitian Lapangan (Field Research) Merupakan riset yang dilakukan secara langsung pada Koperasi Perikanan Sinar Mutiara Samudra Di Desa Swarangan Kecamatan Jorong Kabupaten Tanah Laut yang dijadikan objek penelitian, Kegiatan ini dilakukan agar penulis dapat mengumpulkan data yang berhubungan langsung dengan permasalahan yang dikemukakan yang kemudian dianalisa dengan cara:

a. Observasi

Yaitu suatu cara pengumpulan data dengan cara mengadakan kunjungan dan pengamatan langsung di Koperasi Perikanan Sinar Mutiara Samudra Di Desa Swarangan Kecamatan Jorong Kabupaten Tanah Laut, Hal ini sudah dilakukan selama penulisan tesis ini berlangsung.

b. Dokumentasi 
Dokumentasi yang dilakukan yaitu dengan mendapatkan data yang telah ada dan telah dibukukan sebelumnya.

c. Kuesioner

Yaitu teknik pengumpulan data melalui daftar pertanyaan (angket) yang diajukan kepada pihak-pihak yang berhubungan langsung dengan masalah yang akan diteliti. Kuesioner yaitu teknik pengumpulan data melalui daftar pertanyaan yang diajukan kepada responden yang berhubungan langsung dengan masalah yang akan diteliti dan diisi oleh responden sendiri.

\section{Teknik Analisis Data}

\section{Intrumen Penelitian}

Pengukuran variabel dalam penelitian ini menggunakan skala likert. Skala likert digunakan untuk mengukur sikap, pendapat, dan persepsi seseorang atau sekelompok orang tentang fenomena sosial.

Skala ini meminta responden menunjukan tingkat persetujuan atau ketidaksetujuannya terhadap serangkaian pertanyaan tentang suatu objek (Sugiyono, 2012:56).

Alat ukur yang digunakan adalah kuesioner yang akan diuji validitas dan reliabilitasnya, Produktivitas Kerja akan diukur dari pengaruh Bantuan Pemerintah, Pengalaman dan Lingkungan Usaha. Untuk masingmasing responden mempunyai 5 alternatif jawaban (Skala Likert). Masing-masing prioritas dari kelima point tersebut, yaitu:

1. Sangat setuju (SS) : diberi nilai 5

2. Setuju (S) diberi nilai 4

3. Netral (N) / Ragu (R) : diberi nilai 3

4. Tidak setuju (TS) diberi nilai 2

5. Sangat tidak setuju (STS) diberi nilai 1
Untuk dapat dinyatakan bahwa hasil kuesioner yang disebarkan kepada responden dapat membuktikan bahwa jawaban responden adalah baik dan dapat dipercaya dari jawaban dari responden yang nantinya dipergunakan untuk dijadikan alat pembuktian hipotesa maka diperlukan uji sebagai berikut:

\section{a) Uji Validitas}

Uji validitas adalah untuk mengetahui tingkat kevalidan dari instrumen kuesioner yang digunakan dalam mengumpulkan data. Uji validitas ini dilakukan untuk mengetahui apakah item-item yang tersaji dalam kuesioner benar-benar mampu mengungkapkan dengan pasti apa yang diteliti.

Cara yang digunakan adalah dengan Analisa Item, dimana setiap nilai yang ada pada setiap butir pertanyaan dikorelasikan dengan nilai total seluruh butir pertanyaan untuk suatu variabel dengan menggunakan rumus Korelasi Product Moment (Sugiyono 2012:73).

Lebih lanjut, Sugiyono menyatakan bahwa biasanya syarat minimum untuk dianggap memenuhi syarat adalah kalau $\mathrm{r} \geq$ 0,3 . Jadi apabila korelasi antara butir dengan skor total kurang dari 0,3 maka butir dalam instrumen tersebut dinyatakan tidak valid.

Uji validitas dengan menggunakan korelasi Product Moment dengan formulasi :

$$
r_{x y}=\frac{\Sigma x y}{\left(\Sigma x^{2}\right)\left(\Sigma y^{2}\right)}
$$

\section{b) Uji Reliabilititas}

Uji reliabilitas dimaksudkan untuk mengetahui adanya konsistensi alat ukur dalam penggunaannya, atau dengan kata lain alat ukur tersebut mempunyai hasil yang konsisten apabila digunakan berkali-kali pada waktu yang berbeda. Untuk uji reliabilitas 
ini digunakan Teknik Alpha Cronbach, dimana suatu instrumen dapat dikatakan handal (reliabel) apabila memiliki koefisien keandalan atau alpha sebesar 0,6 atau lebih (Arikunto 2012:22). Adapun formula dari alpha cronbach adalah sebagai berikut :

$$
r_{11}=\left(\frac{k}{k-1}\right)\left(1-\frac{\sum \sigma_{b}^{2}}{\sigma_{t}^{2}}\right)
$$

\section{Dimana :}

$\mathrm{R}_{11}=$ reliabilitas instrumen

$\mathrm{K}=$ banyaknya butir pertanyaan atau banyaknya soal

$\sigma_{\mathrm{b}}{ }^{2} \quad=$ jumlah varians butir

$\sigma_{\mathrm{t}}^{2}=$ varians total (Arikunto, 2012)

Taraf signifikan digunakan 5\%. Jika $\mathrm{r}$ hitung ( $\mathrm{r}$ alpha) > $\mathrm{r}$ tabel, maka instrumen tersebut dinyatakan reliabel. Sebaliknya jika $r$ alpha positif dan $\mathrm{r}$ alpha $<\mathrm{r}$ tabel, maka butir atau variabel tersebut tidak reliabel. Sugiyono (2012:45) menyebutkan bila $\mathrm{r}$ hitung ( $\mathrm{r}$ alpha) $>0,600$, maka instrumen tersebut dinyatakan reliabel. Arikunto (2012:49), tingkat reliabelitas instrumen bisa dilihat dari $r$ hitung ( $r$ alpha) dengan kriteria seperti pada tabel 1:

Tabel 1 Kriteria untuk $r$ hitung ( $r$ alpha)

\begin{tabular}{|c|c|}
\hline $\boldsymbol{r}$ hitung $(\boldsymbol{r}$ alpha) & Kriteria \\
\hline $0,800-1,00$ & sangat tinggi \\
\hline $0,600-0,799$ & tinggi \\
\hline $0,400-0,599$ & cukup \\
\hline $0,200-0,399$ & rendah \\
\hline$<0,200$ & sangat rendah \\
\hline
\end{tabular}

Sumber : Arikunto (2012).

\section{Uji Asumsi Klasik}

Untuk memastikan apakah variabel-variabel penelitian dapat dianalisis dengan menggunakan Regresi Linier Berganda atau tidak, maka diperlukan suatu uji asumsi klasik sebagai persyaratan analisis regresi berganda. Variabel-variabel tersebut harus memenuhi syarat-syarat sebagai berikut:

\section{1) Uji Multikolinieritas}

Uji multikolinieritas ini digunakan untuk mengetahui ada tidaknya korelasi antara variabel independen. Jika terjadi korelasi, maka dinamakan terdapat problem multikolinieritas. Untuk mengetahui ada tidaknya multikolinieritas antar variabel, dapat dilihat dari Variable Inflation Factor (VIF) dari masingmasing variabel bebas terhadap variabel terikat. Menurut Santoso (2008: 357), jika nilai VIF tidak lebih besar dari 5 maka dalam model tidak terdapat multikolinieritas.

\section{2) Uji Heteroskedastisitas}

Uji heteroskedastisitas bertujuan untuk menguji apakah dalam sebuah model regresi terjadi ketidaksamaan varian dari residual dari suatu pengamatan lainnya. Jika varian dari pengamatan lainnya tetap, maka disebut homoskedastisitas. Sedangkan apabila variannya berbeda dari satu pengamatan ke pengamatan lainnya disebut dengan gejala heteroskedastisitas. Untuk mengetahui ada atau tidaknya gejala heteroskedastisitas adalah dengan melihat ada tidaknya pola tertentu pada grafik scatter plot. Apabila tidak ada pola yang jelas atau pola tertentu serta titik menyebar di atas dan di bawah angka 0 pada sumbu $\mathrm{Y}$, maka tidak terjadi heteroskedastisitas.

\section{3) Uji Normalitas}

Uji Normalitas dilakukan dengan tujuan untuk mengetahui apakah dalam sebuah model regresi baik itu variabel terikat maupun variabel bebas secara terpisah atau secara bersamaan keduanya mempunyai distribusi normal atau tidak. Deteksi normalitas dilakukan dengan melihat penyebaran data (titik) pada sumbu diagonal dari 
grafik. Dasar pengambilan keputusan yang digunakan:

1. Jika data menyebar di sekitar garis diagonal dan mengikuti arah garis diagonal, maka model regresi memenuhi asumsi normalitas.

2. Jika data menyebar jauh dari garis diagonal, maka model regresi tidak memenuhi asumsi normalitas (Santoso, 2008:214).

\section{Analisis Regresi Berganda.}

Untuk mengetahui pengaruh variabel bebas terhadap variabel terikatnya menurut Anwar (2012:309) dengan bantuan SPSS Versi 21.0 digunakan rumus analisis regresi linier berganda sebagai berikut:

$\mathrm{y}=\mathrm{a}+\mathrm{b}_{1} \mathrm{x}_{1}+\mathrm{b}_{2} \mathrm{x}_{2}+\mathrm{b}_{3} \mathrm{x}_{3}+\mathrm{e}$

dimana :

$\mathrm{y} \quad=\quad$ dependent variabel

(Produktivitas Kerja)

a $\quad=\quad$ konstata

$\mathrm{b}_{1}, \mathrm{~b}_{2}, \mathrm{~b}_{3}=$ koefisien regresi

$\mathrm{n} \quad=\quad$ banyaknya sampel

$\mathrm{X}_{1}, \quad=\quad$ independent variabel

Bantuan Pemerintah

$\mathrm{X}_{2} \quad=\quad$ independent variabel

Pengalaman

$\mathrm{X}_{3}=$ independent variabel

Lingkungan Usaha

\section{Pengujian Hipotesis}

\section{a) Uji Hipotesis I (Uji F)}

Untuk menguji kebenaran hipotesis pertama digunakan uji $\mathrm{F}$ yaitu untuk menguji keberartian/signifikansi regresi secara keseluruhan dengan rumus hipotesis sebagai berikut:

$\mathrm{H}_{0} \quad: \quad \mathrm{b}_{1}=\mathrm{b}_{2}=\mathrm{b}_{3}=\mathrm{b}_{4}=0$, Artinya variasi dari model regresi berhasil menerangkan variasi variabel bebas secara keseluruhan, sejauh mana pengaruhnya terhadap variabel tidak bebas (variabel terikat)

$\mathrm{H}_{\mathrm{a}} \quad: \quad b_{1} \neq \mathrm{b}_{2} \neq \mathrm{b}_{3} \neq \mathrm{b}_{4} \neq$ 0

Artinya variasi dari model regresi tidak berhasil menerangkan variasi variabel bebas secara keseluruhan, sejauh mana pengaruhnya terhadap variabel tidak bebas (variabel terikat)

Pengujian dengan uji $\mathrm{F}$ variansnya adalah dengan membandingkan $\mathrm{F}_{\text {hitung }}\left(\mathrm{F}_{\mathrm{h}}\right)$ dengan $\mathrm{F}_{\text {tabel }}\left(\mathrm{F}_{\mathrm{t}}\right)$ pada $\alpha=$ 0,05 apabila hasil perhitungannya menunjukkan:

1. $\mathrm{F}_{\mathrm{h}}>\mathrm{F}_{\mathrm{t}}$, maka $\mathrm{H}_{0}$ ditolak dan $\mathrm{H}_{\mathrm{a}}$ diterima

Artinya variasi dari model regresi berhasil menerangkan variasi variabel bebas secara keseluruhan, sejauh mana pengaruhnya terhadap variabel tidak bebas (variabel terikat).

2. $\mathrm{F}_{\mathrm{h}}<\mathrm{F}_{\mathrm{t}}$, maka $\mathrm{H}_{0}$ diterima dan $\mathrm{H}_{\mathrm{a}}$ ditolak

Artinya variasi dari model regresi tidak berhasil menerangkan variasi variabel bebas secara keseluruhan, sejauh mana pengaruhnya terhadap variabel tidak bebas (variabel terikat).

\section{b) Uji Hipotesis II (Uji t)}

Untuk menguji kebenaran hipotesis kedua langkah pertama yang dilakukan adalah pengujian secara parsial melalui uji t. Adapun rumusan hipotesis dengan menggunakan Uji $\mathrm{t}$ adalah sebagai berikut:

$\mathrm{H}_{0} \quad: \quad \mathrm{b}_{1}=\mathrm{b}_{2}=\mathrm{b}_{3}=\mathrm{b}_{4}=0$

Artinya variasi variabel bebas dapat menerangkan variabel tidak bebas (variabel terikat) dan terdapat pengaruh diantara kedua variabel yang diuji

$\mathrm{H}_{\mathrm{a}} \quad: \quad \mathrm{b}_{1} \neq \mathrm{b}_{2} \neq \mathrm{b}_{3} \neq \mathrm{b}_{4} \neq$ 0

Artinya variasi variabel bebas tidak dapat menerangkan variabel tidak bebas (variabel terikat) dan terdapat pengaruh antara dua variabel yang diuji.

Pengujian dilakukan melalui uji $\mathrm{t}$ dengan membandingkan thitung $\left(t_{h}\right)$ dengan $\mathrm{t}_{\text {tabel }}\left(\mathrm{t}_{\mathrm{t}}\right)$ pada $\alpha 0,05$. Apabila hasil perhitungan menunjukkan:

1. $t_{h} \geq t_{t}$ maka $H_{0}$ ditolak dan $H_{a}$ diterima 
Artinya variasi variabel bebas dapat menerangkan variabel tidak bebas (variabel terikat) dan terdapat pengaruh diantara kedua variabel yang diuji.

2. $t_{\mathrm{h}}<\mathrm{t}_{\mathrm{t}}$ maka $\mathrm{H}_{0}$ diterima dan $\mathrm{H}_{\mathrm{a}}$ ditolak

Artinya variasi variabel bebas tidak dapat menerangkan variabel tidak bebas (variabel terikat) dan terdapat pengaruh antara dua variabel yang diuji.

\section{c) Variabel Dominan}

Untuk mengetahui seberapa besar kontribusi masing-masing variabel bebas dan yang paling menentukan (dominan) pengaruhnya terhadap variabel terikat suatu model regresi linier, maka digunakan koefisien Beta (Beta Coefficient) setiap variabel yang distandarisasi (standardized cofficient). Nilai beta $(\beta)$ terbesar menunjukkan bahwa variabel bebas tersebut mempunyai pengaruh yang dominan terhadap variabel terikat. (Sritua, 2012:12).

\section{Analisis Hasil Penelitian}

Sebagaimana telah dirumuskan sebelumya pada Bab III bahwa dalam penelitian ini sesuai dengan hipotesis :

1. Terdapat pengaruh yang positif dan signifikan Bantuan Pemerintah, Pengalaman dan Lingkungan Usaha secara simultan terhadap Produktivitas Kerja Nelayan Koperasi Perikanan Sinar Mutiara Samudra Di Desa Swarangan Kecamatan Jorong Kabupaten Tanah Laut

2. Terdapat pengaruh yang positif dan signifikan Bantuan Pemerintah, Pengalaman dan Lingkungan Usaha secara parsial terhadap Produktivitas Kerja Nelayan Koperasi Perikanan Sinar Mutiara Samudra Di Desa Swarangan Kecamatan Jorong Kabupaten Tanah Laut.

3. Variabel yang berpengaruh dominan terhadap Produktivitas Kerja Nelayan Koperasi Perikanan Sinar Mutiara Samudra Di Desa Swarangan
Kecamatan Jorong Kabupaten Tanah Laut adalah Bantuan Pemerintah (X1).

Pengujian dilakukan dengan tingkat kepercayaan $95 \%$ atau tingkat signifikansi $0,05(\mathrm{a}=0,05)$ dan dengan nilai t tabel $=$ $\mathrm{df}=\mathrm{n}-\mathrm{k}-1=51-4-1=46$ maka di dapat nilai $\mathrm{t}$ tabel $=2,013$ dan nilai $\mathrm{f}$ tabel dalam penelitian ini yaitu df1=k-1=4-1=3 dan $\mathrm{df} 2=\mathrm{n}-\mathrm{k}=51-4=47$ maka di dapat nilai $\mathrm{F}$ tabel $=3,20$ Untuk mengkaji kebenaran hipotesis - hipotesis tersebut digunakan analisis regresi linier berganda.

Tabel 2 Rekapitulasi Analisis Regresi Linier Berganda Pengaruh Bantuan Pemerintah (X1), Pengalaman (X2) dan Lingkungan Usaha Terhadap Produktivitas Kerja (Y) Nelayan

\begin{tabular}{|c|c|c|c|c|c|}
\hline Variabel & $\begin{array}{c}\text { Koefisien } \\
\text { Regresi (bi) }\end{array}$ & $\begin{array}{c}\mathrm{t} \\
\text { hitun } \\
\mathrm{g}\end{array}$ & $\begin{array}{c}\mathrm{t} \\
\text { tab } \\
\mathrm{el}\end{array}$ & $\begin{array}{c}\text { Bet } \\
\mathrm{a}\end{array}$ & sig \\
\hline Konstanta & 1,406 & & & & \\
\hline $\begin{array}{l}\text { Bantuan } \\
\text { Pemerintah (X1) }\end{array}$ & 0,432 & $\begin{array}{c}3,21 \\
0\end{array}$ & $\begin{array}{l}1,9 \\
60\end{array}$ & $\begin{array}{l}0,3 \\
56\end{array}$ & $\begin{array}{l}0,0 \\
02\end{array}$ \\
\hline $\begin{array}{l}\text { Pengalaman } \\
\text { (X2) }\end{array}$ & 0,254 & $\begin{array}{c}2,44 \\
5\end{array}$ & $\begin{array}{l}1,9 \\
60 \\
\end{array}$ & $\begin{array}{l}0,2 \\
53 \\
\end{array}$ & $\begin{array}{c}0,0 \\
18 \\
\end{array}$ \\
\hline $\begin{array}{l}\text { Lingkungan } \\
\text { Usaha (X3) }\end{array}$ & 0,116 & $\begin{array}{c}3,42 \\
5\end{array}$ & $\begin{array}{l}1,9 \\
60\end{array}$ & $\begin{array}{c}0,3 \\
68\end{array}$ & $\begin{array}{l}0,0 \\
00\end{array}$ \\
\hline \multicolumn{2}{|l|}{ Konstanta $=1,406$} & \multicolumn{4}{|c|}{ F hitung $=29,885$} \\
\hline \multicolumn{2}{|c|}{ Multiple $\mathrm{R}=0,505$} & \multicolumn{4}{|c|}{$\mathrm{F}$ tabel $=3,20$} \\
\hline \multicolumn{2}{|c|}{$\mathrm{R}$ square $\left(\mathrm{R}^{2}\right)=0,630$} & \multicolumn{4}{|c|}{ Sig $=0,000$} \\
\hline
\end{tabular}

Pada tabel 2 diatas dapat dilihat $\mathrm{R}$ Square sebesar 0,630 yang berarti besarnya variasi sumbangan seluruh variabel bebas terhadap variabel terikatnya adalah $63 \%$ sedangkan sisanya $37 \%$ dijelaskan oleh sebab lain diluar dari penelitian ini.

Interpretasi terhadap konstanta $(1,406)$ pengukuran dalam penelitian ini dimana variabel dengan menggunakan skala Likert antara 1 sampai dengan 5 maka tidak boleh diinterpretasikan bahwa jika variabel Bantuan Pemerintah (X1), Pengalaman (X2) dan Lingkungan Usaha (X3) bernilai nol, karena ketiga variabel tersebut tidak mungkin bernilai nol karena Skala Likert terendah yang digunakan adalah 1 dan berdasarkan hasil perhitungan spss versi 21.0 dalam penelitian ini nilai konstanta adalah 1,406 dan termasuk dalam kategori sedang. 
Berdasarkan tabel 2 diperoleh persamaan regresi sebagai berikut:

\section{$Y=1,406+0,432 \times 1+0,254 \times 2+0,116$ $\mathrm{X} 3+\mathrm{ei}$}

Adapun penjelasan dari persamaan regresi diatas adalah sebagai berikut :

1. Jika koefisien $0,432 \quad \mathrm{X} 1$ variabel Bantuan Pemerintah meningkat dengan asumsi Koefisien 0,432, jika X2 variabel Pengalaman Koefisien 0,254 dan X3 Lingkungan Usaha Koefisien 0,116 tetap, maka Produktivitas Kerja juga akan meningkat.

2. Jika koefisien 0,254 X2 variabel Pengalaman meningkat dengan asumsi Koefisien 0,432 X1 variabel Bantuan Pemerintah dan X3 Lingkungan Usaha Koefisien 0,116 tetap, maka Produktivitas Kerja juga akan meningkat.

3. Jika koefisien $0,116 \quad \mathrm{X} 3$ variabel Pengalaman meningkat dengan asumsi Koefisien 0,432 X1 dan jika X2 variabel Pengalaman Koefisien 0,254 variabel Bantuan Pemerintah tetap, maka Produktivitas Kerja juga akan meningkat.

Berdasarkan persamaan tersebut, menunjukkan bahwa semua variabel bebas memiliki koefisien regresi positif. Hal ini berarti variabel Bantuan Pemerintah (X1) dan mempunyai hubungan yang searah atau berbanding lurus dengan variabel terikatnya atau Produktivitas Kerja (Y). Artinya, jika variabel X1, X2 dan X3 mengalami kenaikan maka variabel terikatnya $\mathrm{Y}$ juga ikut mengalami kenaikan, dan jika variabel X1, X2 dan X3 mengalami penurunan, maka variabel terikatnya $\mathrm{Y}$ akan mengalami penurunan.

\section{Uji Hipotesis}

\section{Uji Hipotesis I: Uji F Secara Simultan}

Uji ini digunakan dengan tujuan untuk membuktikan apakah variabel bebas berpengaruh secara bersama-sama terhadap variabel terikat. Dalam menjawab hipotesis yang telah diajukan pada awal penelitian, menggunakan alat bantu analisis software SPSS versi 21.00. Dari hasil perhitungan melalui SPSS menunjukan dan signifikansi 0,000 maka dapat disimpulkan variabel bebas berpengaruh signifikan terhadap variabel terikatnya karena signifikansi adalah $0,000<0,05$ dan $F_{\text {hitung }} 29,885$ $>3,20$, sehingga hipotesis pertama yang mengatakan Terdapat pengaruh yang positif dan signifikan Bantuan Pemerintah, Pengalaman dan Lingkungan Usaha secara simultan terhadap Produktivitas Kerja Nelayan Koperasi Perikanan Sinar Mutiara Samudra Di Desa Swarangan Kecamatan Jorong Kabupaten Tanah Laut dapat diterima atau teruji.

2. Secara Parsial

Uji Hipotesis II : Uji t

Melalui pengujian ini akan dapat diketahui apakah variabel yang terdiri dari Bantuan Pemerintah (X1), Pengalaman (X2) dan Lingkungan Usaha (X3) berpengaruh secara parsial terhadap Produktivitas Kerja (Y) Koperasi Perikanan Sinar Mutiara Samudra Jorong Kabupaten Tanah Laut, yaitu dengan cara membandingkan nilai probability signifikansi variabel dengan probability sebesar 5\% $(\alpha=0,05)$ apabila nilai probability signifikansi < $(\alpha=0,05)$ maka terdapat pengaruh signifikan terhadap variabel terikatnya, begitu juga sebaliknya, adapun hasil perhitungan statistik dapat di lihat pada tabel 3 dibawah ini

Tabel 3 Nilai $t$ hitung

\begin{tabular}{|c|c|c|c|c|c|}
\hline $\begin{array}{c}\text { Variabel } \\
\text { bebas }\end{array}$ & $\begin{array}{c}\mathrm{t} \\
\text { hit } \\
\text { un } \\
\mathrm{g}\end{array}$ & $\begin{array}{c}\mathrm{t} \\
\mathrm{ta} \\
\mathrm{b} \\
\mathrm{el}\end{array}$ & $\begin{array}{l}\mathrm{Si} \\
\mathrm{g} .\end{array}$ & Keterangan & $\begin{array}{l}\text { Signifikan } \\
\text { atau tidak } \\
\text { signifikan }\end{array}$ \\
\hline $\begin{array}{l}\text { X1 } \\
\text { Bantuan } \\
\text { Pemerint } \\
\text { ah } \\
\end{array}$ & $\begin{array}{l}3,2 \\
10\end{array}$ & $\begin{array}{l}1, \\
9 \\
6 \\
0\end{array}$ & $\begin{array}{l}0, \\
0 \\
0 \\
2\end{array}$ & $\begin{array}{l}0,002<0,05 \text { dan } \\
\mathrm{t}_{\text {hitung }} 3,210> \\
\mathrm{t}_{\text {tabel }} 1,960\end{array}$ & Signifikan \\
\hline $\begin{array}{l}\mathrm{X} 2 \\
\text { Pengalam } \\
\text { an }\end{array}$ & $\begin{array}{l}2,4 \\
45\end{array}$ & $\begin{array}{l}1, \\
9 \\
6 \\
0\end{array}$ & $\begin{array}{l}0, \\
0 \\
1 \\
8\end{array}$ & $\begin{array}{l}0,018<0,05 \text { dan } \\
\mathrm{t}_{\text {hitung }} 2,445> \\
\mathrm{t}_{\text {tabel }} 1,960\end{array}$ & Signifikan \\
\hline $\begin{array}{l}\text { X3 } \\
\text { Lingkung } \\
\text { an Usaha }\end{array}$ & $\begin{array}{l}3,4 \\
25\end{array}$ & $\begin{array}{l}1, \\
9 \\
6 \\
0\end{array}$ & $\begin{array}{l}0, \\
0 \\
0 \\
1\end{array}$ & $\begin{array}{l}0,001<0,05 \text { dan } \\
\mathrm{t}_{\text {hitung }} 3,425> \\
\mathrm{t}_{\text {tabel }} 1,960\end{array}$ & Signifikan \\
\hline
\end{tabular}


Berdasarkan tabel 3 dapat dilihat Pengaruh variabel Bantuan Pemerintah (X1) terhadap Produktivitas Kerja (Y). Hal ini dapat dilihat dari tabel 5.13 dimana memiliki nilai probability signifikansi yaitu $0,002<0,05$ dan $t_{\text {hitung }} 3,210>t_{\text {tabel }}$ 1,960, sehingga dapat disimpulkan bahwa Bantuan Pemerintah (X1) berpengaruh siginifikan secara sendiri - sendiri atau parsial terhadap Produktivitas Kerja (Y) Koperasi Perikanan Sinar Mutiara Samudra Jorong Kabupaten Tanah Laut .

Pengaruh variabel Pengalaman (X2) terhadap Produktivitas Kerja (Y), Pengalaman (X2) berpengaruh signifikan secara parsial terhadap Produktivitas Kerja (Y). Hal ini dapat dilihat dari tabel 5.11 dimana nilai probability signifikansi yaitu $0,018<$ 0,05 dan thitung $2,445>t_{\text {tabel }} 1,960$, sehingga dapat disimpulkan bahwa parsial Pengalaman (X2) berpengaruh siginifikan secara sendiri - sendiri atau parsial terhadap Produktivitas Kerja (Y) Koperasi Perikanan Sinar Mutiara Samudra Jorong Kabupaten Tanah Laut

Pengaruh variabel Lingkungan Usaha (X3) terhadap Produktivitas Kerja (Y), Lingkungan Usaha (X3) berpengaruh signifikan secara parsial terhadap Produktivitas Kerja (Y). Hal ini dapat dilihat dari tabel 5.11 dimana nilai probability signifikansi yaitu $0,001<0,05$ dan $t_{\text {hitung }} 3,425>t_{\text {tabel }}$ 1,960 , sehingga dapat disimpulkan bahwa parsial Lingkungan Usaha (X3) berpengaruh siginifikan secara sendiri - sendiri atau parsial terhadap Produktivitas Kerja (Y) Koperasi Perikanan Sinar Mutiara Samudra Jorong Kabupaten Tanah Laut.

Dengan demikian hipotesis kedua yang mengatakan Terdapat pengaruh yang positif dan signifikan Bantuan Pemerintah, Pengalaman dan Lingkungan Usaha secara parsial terhadap Produktivitas Kerja Nelayan Koperasi Perikanan Sinar Mutiara
Samudra Di Desa Swarangan Kecamatan Jorong Kabupaten Tanah Laut adalah benar atau teruji.

3. Uji Hipotesis III: Variabel Yang Berpengaruh Dominan

Pada hipotesa ketiga yang menyatakan bahwa Bantuan Pemerintah (X1) merupakan faktor yang paling berpengaruh terhadap Produktivitas Kerja (Y) adalah salah atau tidak terbukti, karena hasil penelitian menunjukkan variabel yang berpengaruh dominan terhadap Produktivitas Kerja adalah Lingkungan Usaha (X3) karena memiliki nilai Beta (Beta Coefficient) sebesar 0,368> nilai Beta (Beta Coefficient) Pengalaman (X2) yang hanya sebesar 0,253 dan Bantuan Pemerintah (X3) yang hanya sebesar 0,356 .

\section{Kesimpulan}

Berdasarkan hasil analisis dan pembahasan yang telah diuraikan pada bab-bab sebelumnya, maka kesimpulan penelitian ini adalah:

1. Pengaruh ketiga variabel Bantuan Pemerintah, Pengalaman dan Lingkungan Usaha, tersebut secara simultan (bersama-sama) berpengaruh signifikan terhadap Produktivitas Kerja Nelayan Koperasi Perikanan Sinar Mutiara Samudra Di Desa Swarangan Kecamatan Jorong Kabupaten Tanah Laut

2. Variabel Bantuan Pemerintah, Pengalaman dan Lingkungan Usaha berpengaruh signifikan terhadap Produktivitas Kerja Nelayan Koperasi Perikanan Sinar Mutiara Samudra Di Desa Swarangan Kecamatan Jorong Kabupaten Tanah Laut secara parsial.

3. Hasil penelitian menyatakan bahwa variabel yang berpengaruh dominan terhadap Produktivitas Kerja Nelayan Koperasi Perikanan Sinar Mutiara Samudra Di Desa Swarangan Kecamatan Jorong Kabupaten Tanah Laut adalah Lingkungan Usaha. 


\section{Daftar Pustaka}

$\begin{array}{llr}\text { Afrillia, } & \text { Pratiwi .2016. } & \text { Pengaruh } \\ & \text { Pengalaman } & \text { Kerja, } \\ & \text { Kemampuan } & \text { Kerja, } \\ & \text { Fasilitas, Pembagian Kerja } \\ & \text { Dan Teamwork } & \text { Terhadap } \\ & \text { Produktivitas } & \text { Kerja } \\ \text { Nelayan } & \text { Budidaya } & \text { Kuda } \\ \text { Laut } & \text { Kampung } & \text { X } \\ & \end{array}$

http://repository.umrah.ac.id

l. Diakses 29 desember 2020.

Agustin .2014. Hubungan antara produktivitas kerja terhadap pengembangan karir pada karyawan PT Bank Mandiri Tarakan. eJournal Psikologi, 02(01), 24 - 40.

Nuzsep. 2004. Hubungan Antara Kepuasan Kerja dengan Produktivitas Kerja Karyawan. Jurnal PSYCHE. Vol. 1, No. 1, Desember 2004.

Anwar, Sanusi .2012. Metodologi Penelitian Bisnis. Salemba. Jakarta.

Arikunto, Suharsimi. 2006. Prosedur Penelitian : Suatu Pendekatan Praktik, Edisi. Revisi VI, PT Rineka Cipta. Jakarta.

\section{Prosedur}

Penelitian Suatu Pendekatan Praktik. Rineka Cipta. Jakarta.

Asih, Tyas. 2012. Pengaruh Pengalaman Terhadap Peningkatan Keahlian Auditor. Dalam Bidang Auditing. Skripsi. Jurusan Akuntansi Fakultas Ekonomi. UII. Yogyakarta.

Braglia, M. and Petroni, A. (2000). A Quality Assurance-oriented Methodology for Handling Trade-offs in Supplier Selection. International Journal of Physical Distribution and Logistics Management. 30(2), 96-111.
Buchory, Herry Achmad dan Saladin, Djaslim .2010. Manajemen Pemasaran. Linda Karya. Bandung.

Buletin Teknis Nomor 10 Standar Akuntansi Pemerintahan tentang Akuntansi Belanja Bantuan Sosial.

I Gusti Putu Darya (2011). Pengaruh Ketidakpastian Linkungan dan Karakteristik Kewirausahaan Terhadap Kompetensi Usaha dan Kinerja Usaha Mikro Kecil di Kota Balikpapan. Inovasi dan Kewirausahaan, Vol. 1, No. 1 Januari 2011.

Dea Kamalia Putri, Nuraini Asriati, Parijo. 2018. Pengaruh Bantuan Dana Usaha Produktif Terhadap Pendapatan Nelayan Di Desa Sungai Limau Kabupaten Mempawah.

https://jurnal.untan.ac.id/. Diakses 29 desember 2020.

Dessler, Gary .2004. Manajemen Sumber Daya Manusia. Salemba. Empat. Jakarta.

Edyun, Neti Saputri .2012. Hubungan Antara Stres Kerja Dengan Produktivitas Karyawan Pada CV. Mediatama Surakarta. Universitas Muhammdiyah. Surakarta.

Eriksson, 2008. Childhood and Society. Norton. New York .

Foster, 2001. Pembinaan untuk Kinerja Karyawan. PPM. Jakarta.

Handoko. T. Hani .2004. Manajemen dan Sumber Daya Manusia, ,. Liberty. Yogyakarta. .2009. Manajemen Personalia dan Sumber Daya Manusia. BPFE, Yogyakarta.

Hasibuan, Malayu. SP .2003. Manajemen SDM. Edisi Revisi, Cetakan Ke. Tigabelas. Bumi Aksara. Jakarta .

Johnson, Elaine B .2007 Contextual Teaching and Learning: 
$\begin{array}{lr}\text { Menjadikan. } & \text { Kegiatan } \\ \text { Belajar } & \text { Mengajar } \\ \text { Mengasyikan dan Bermakna. } & \text { Kaifa. Bandung. }\end{array}$

Kusnadi, 2002. Filosofi Pemberdayaan

Masyarakat Pesisir.

Humaniora. Bandug.

Maurits .2010. Selintas Tentang Kelelahan

Kerja. Amara Books.

Yogyakarta.

Nadia June Mawa Dewayanti. 2018.

Pengaruh Pengalaman Kerja,

Modal, Jam Kerja Dan

Jumlah Anggota Keluarga

Terhadap Pendapatan

Nelayan Di Desa

Asemdoyong Kecamatan

Taman, Kabupaten

Pemalang.

http://eprints.undip.ac.id/.

Diakses 29 desember 2020

Peraturan Menteri Keuangan Republik

Indonesia Nomor 81 Tahun

2012 Tentang Belanja

Bantuan Sosial Pada

Kementerian

Negara/Lembaga

Pemerintah Provinsi Kalimantan Selatan

kepada nelayan di dasarkan pada Peraturan Gubernur Nomor 75 Tahun 2020 Tentang Perubahan kedua Atas Peraturan Gubernur Nomor 0105 Tahun 2018 tentang Tata Cara Penganggaran, Pelaksanaan dan Penatausahaan, Pertanggungjawaban dan Pelaporan serta Monitoring dan Evaluasi Hibah dan Bantuan Sosial Yang Bersumber dari Anggaran Pendapatan dan Belanja Daerah.

Peraturan Direktorat Jendral Pengelolaan Ruang Laut Nomor 5/PER/DJPRL/2020 Tentang Petunjuk Teknis Penyaluran Bantuan Pemerintah Saran dan Prasarana di Wilayah Pesisir dan Pulau Pulau Kecil Tahun 2020

Peraturan Gubernur Kalimantan Selatan Nomor 0105 Tahun 2018 tentang Tata Cara Penganggaran, Pelaksanaan Penatausahaan,

Pertanggungjawaban dan Pelaporan serta Monitoring dan Evaluasi Hibah dan Bantuan Sosial Yang Bersumber dari Anggaran Pendapatan dan Belanja Daerah

Peraturan Kementrian Kelautan dan Perikanan nomor per. $15 / \mathrm{men} / 2010$ tentang Organisasi Dan Tata Kerja Kementrian Kelautan Dan Perikanan

Peraturan Menteri Dalam Negeri Republik Indonesia Nomor 123 Tahun 2018 Tentang Perubahan Keempat Atas Peraturan Menteri Dalam Negeri Nomor 32 Tahun 2011 Tentang Pedoman Pemberian Hibah Dan Bantuan Sosial Yang Bersumber Dari Anggaran Pendapatan Dan Belanja Daerah

Peraturan Menteri Kelautan Dan Perikanan Republik Indonesia Nomor 2/Permen-Kp/2015 Tentang Larangan Penggunaan Alat Penangkapan Ikan Pukat Hela .Trawls) Dan Pukat Tarik .Seine Nets) Di Wilayah Pengelolaan Perikanan Negara Republik Indonesia

Pratiwi Afrillia. 2019. Pengaruh Pengalaman Kerja, Kemampuan Kerja, Fasilitas, Pembagian Kerja dan Teamwork Terhadap Produktivitas Kerja Nelayan Budidaya Kuda Laut Kampung Melayu Senggarang Tanjungpinang Kota. 
http://repository.umrah.ac.id/.

Diakses 29 desember 2020.

Puspaningsih, Abriyani .2004. Faktorfaktor yang berpengaruh Terhadap Kepuasan Kerja Dan Kinerja Manajer Perusahaan Manufaktur", Jurnal Akuntansi dan Auditing Indonesia, Jakarta

Rivai, Veitzhal .2009. Manajemen Sumber Daya Manusia untuk Perusahaan : dari Teori Ke Praktik, Edisi Pertama, Penerbit PT. Raja Grafindo Persada,. Jakarta

Santoso, Singgih .2008. Statistik Parametik. PT Gramedia Pustaka. Jakarta.

Singarimbun, Masri .2010. Metode Penelitian Survai. Pustaka Belajar. Jakarta.

Solihah .2012. Analisis Kesulitan Siswa Dalam Proses Pemecahan Masalah Geometri Berdasarkan Tahapan Berfikir Van Hiele." Jurnal Mosharafa. Vol (6) 2.

Sritua, Arief .2012. Metodologi Penelitian Ekonomi, Universitas. Indonesia. Jakarta.

Suci .2008. Panduan Praktis Menyusun Analisis Beban Kerja (1st ed.). Penebar Suadaya Jakarta.

Sudarso .2004. Manajemen Pemasaran Jasa Perhotelan. Deepublish. Yogyakarta .

Sugiono. Dr. 2012. Metode Penelitian Pendidikan Pendekatan Kuantitatif, kualitatif, dan $R \& D$. Alfabeta. Bandung.

Sularso dan Naim .2009. Analisis Pengaruh Pengalaman Akuntan pada Pengetahuan dan Penggunaan Intuisi dalam Mendeteksi Kekeliruan. Jurnal Riset Akuntansi Indonesia, Vol. 2, No. 2, Juli, Hal 154-172
Sularso, Sri .2008. Metode Penelitian Akuntansi Sebuah Pendekatan.Gramedia Jakarta.

Supriyanto, Achmad Sani dan Machfudz, Masyuri .2010. Metodologi Riset: Manajemen Sumberdaya Manusia. UINMaliki Press. Malang.

Suryana .2006. Kewirausahaan Pendoman Praktis: Kiat dan Proses Menuju Sukses. Salemba Empat. Jakarta.

Suyitno, 2012. Prosedur Penelitian Tindakan Kelas. Ghalia. Indonesia. Bogor.

Swamidass \& Newell, 2007. Manufacturing Strategy, Environment Uncertainty and Performance A Path Analytic Model, Management Science, Vol.33, No.4, 508-524

Umar, Husein, 2012. Metode Penelitian. Salemba Empat .Jakarta.

Undang - Undang Nomor 11 tahun 2009 tentang Kesejahteraan Sosial

Ward et al, 1995. At a Glance Sistem Kardiovaskuler. Erlangga. Jakarta.

Wispandono .2010. Pengaruh Lingkungan Bisnis Terhadap Kinerja Pengrajin Industri Batik Di Kabupaten Bangkalan, jurnal mitra ekonomi dan manajemen bisnis, Universitas Trunojoyo, Vol. 1, (2), 152-162 ISSN 20871090. 